\title{
Prediction of cerebral hemorrhagic supratentorial stroke acute period outcome on the basis of the assessment of secondary intraventricular hemorrhage severity in the onset of the disease
}

\author{
A. A. Kuznietsov \\ Zaporizhzhia State Medical University, Ukraine
}

Key words:

cerebral

hemorrhage,

X-Ray tomography,

prognosis.

Pathologia

2017; 14 (3), 326-329

DOI:

10.14739/2310-1237

2017.3.118746

E-mail:

titus3.05@gmail.com
Criteria for a short-term vital and functional prognosis for cerebral hemorrhagic supratentorial stroke (CHSS) acute period, that would take into account the secondary IVH severity in the onset of the disease, are currently lacking.

The main purpose of the study was to develop criteria for the prediction of cerebral hemorrhagic supratentorial stroke acute period outcome on the basis of the assessment of secondary intraventricular hemorrhage (IVH) severity in the onset of the disease.

Materials and methods. A complex clinical and paraclinical study was conducted in 70 patients (38 men and 32 women, aged $66(58 ; 74)$ years) who have CHSS and secondary IVH confirmed by a clinical and neuroimaging examination, who were hospitalized within the first 24 hours since the onset of the disease and received conservative therapy. Intraventricular hemorrhage (IVH) severity was assessed in terms of Graeb Scale, IVH Scale and LeRoux Scale. To determine the prediction criteria, ROC analysis was used, calculating sensitivity (Se) and specificity (Sp) parameters.

Results. Lethal outcome was registered in $18.6 \%$ cases, unfavorable functional outcome (modified Rankin Scale score $(\mathrm{mRS})=4-5$ on the $21^{\text {st }}$ day of the disease $)-$ in $44.3 \%$ patients. It was determined that IVH Scale (AUC $\left.=0.94, P<0.05\right)$ has a higher informative value than Graeb Scale $(A U C=0.89, P<0.05)$ and LeRoux Scale (AUC $=0.88, P<0.05)$ for a lethal prognosis of CHSS acute period outcome. It was detected that Graeb Scale, Intraventicular Hemorrhage Scale and LeRoux Scale are more informative for the determination of vital rather than functional prognosis of CHSS acute period outcome (AUC $=0.89$ versus AUC $=0.74$ for Graeb Scale, $P<0.05 ; A U C=0.94$ versus $A U C=0.79$ for IVH Scale, $P<0.05 ; A U C=0.88$ versus AUC $=0.72$ for LeRoux Scale, $P<0.05$ ).

Conclusions. Predictors of the lethal outcome of CHSS acute period are Graeb Scale score $>5(\mathrm{Se}=84.6 \%, \mathrm{Sp}=77.2 \%)$, IVH Scale score $>16(\mathrm{Se}=84.6 \%, \mathrm{Sp}=96.5 \%)$ and LeRoux Scale score $>9(\mathrm{Se}=84.6 \%, \mathrm{Sp}=86.0 \%)$. Graeb Scale score $\leq 3(\mathrm{Se}=69.2 \%, \mathrm{Sp}=72.7 \%)$, IVH Scale score $<8(\mathrm{Se}=69.2 \%, \mathrm{Sp}=79.5 \%)$ and LeRoux Scale score $\leq 3 \mathrm{Se}=69.2 \%$, $\mathrm{Sp}=72.7 \%$ ) are the criteria for the favourable functional outcome of CHSS acute period (mRS score $\leq 3$ on the 21st day).

\section{Прогнозування виходу гострого періоду мозкового геморагічного супратенторіального інсульту на підставі оцінювання вираженості вторинного внутрішньошлуночкового крововияиву в дебюті захворювання}

мозковий

крововилив, комп'ютерна томографія, прогноз.

\section{А. А. Кузнєцов}

Критерії короткострокового вітального та функціонального прогнозу виходу гострого періоду мозкового геморагічного супратенторіального інсульту (МГCІ), які враховували би вираженість вторинного внутрішньошлуночкового крововиливу (ВШК) у дебюті захворювання, на теперішній час відсутні.

14, № 3(41)

C. 326-329

Мета роботи - розробити критерії прогнозування наслідків гострого періоду МГСІ на підставі оцінювання вираженості вторинного ВШК у дебюті захворювання.

Матеріали та методи. Здійснили комплексне клініко-параклінічне дослідження 70 пацієнтів (38 чоловіків і 32 жінки, вік - $66(58 ; 74)$ років) із підтвердженим за даними клініко-нейровізуалізаційного дослідження МГСІ та вторинним ВШК, які були госпіталізовані в перші 24 години від дебюту захворювання та отримували консервативну терапію. Вираженість вторинного ВШК оцінювали в балах за Graeb Scale, Intraventicular hemorrhage (IVH) Scale i LeRoux Scale. Для визначення критеріїв прогнозування використовувався ROC-аналіз із розрахунком параметрів чутливості (Se) та специфрічності (Sp).

Результати. Летальний вихід зареєстрований у 18,6 \% випадків, несприятливий функціональний вихід у вигляді значення 4-5 балів за модифікованою шкалою Ренкіна (мШР) на 21 добу захворювання - у 44,3 \% пацієнтів. Виявлено, що IVH Scale (AUC = 0,94, p < 0,05) перевищує за інформативністю Graeb Scale (AUC $=0,89, p<0,05)$ i LeRoux Scale $(\mathrm{AUC}=0,88, \mathrm{p}<0,05)$ для прогнозування летального виходу гострого періоду МГСl. Встановлено, що Graeb scale, IVH scale i LeRoux scale інформативніші для визначення вітального, ніж функціонального прогнозу виходу гострого періоду $\mathrm{M \Gamma Cl}(\mathrm{AUC}=0,89$ проти $\mathrm{AUC}=0,74$ для Graeb scale, $\mathrm{p}<0,05 ; \mathrm{AUC}=0,94$ проти $\mathrm{AUC}=0,79$ для IVH scale, $p<0,05$; $\mathrm{AUC}=0,88$ проти $\mathrm{AUC}=0,72$ для LeRoux scale, $\mathrm{p}<0,05)$.

Висновки. Предиктори летального виходу гострого періоду $\mathrm{M \Gamma Cl}$ - значення $>5$ балів за Graeb Scale (Se $=84,6 \%$, $\mathrm{Sp}=77,2 \%),>16$ балів за IVH Scale $(\mathrm{Se}=84,6 \%, \mathrm{Sp}=96,5 \%)$ та >9 балів за LeRoux Scale (Se = 84,6 \%, Sp = 86,0 \%). Критеріями сприятливого функціонального виходу гострого періоду МГСІ ( $\leq 3$ бали за МШР на 21 добу захворювання) $€$ значення за Graeb Scale $\leq 3(\mathrm{Se}=69,2 \%, \mathrm{Sp}=72,7 \%)$, IVH Scale $<8(\mathrm{Se}=69,2 \%, \mathrm{Sp}=79,5 \%)$ i LeRoux Scale $\leq 3$ $(\mathrm{Se}=69,2 \%, \mathrm{Sp}=72,7 \%)$. 


\section{Прогнозирование исхода острого периода мозгового геморрагического супратенториального инсульта на основании оценки выраженности вторичного внутрижелудочкового кровоизлияния в дебюте заболевания}

\section{А. А. Кузнецов}

Критерии краткосрочного витального и функционального прогноза исхода острого периода мозгового геморрагического супратенториального инсульта (МГСИ), которые бы учитывали выраженность вторичного внутрижелудочкового кровоизлияния (ВЖК) в дебюте заболевания, в настоящее время отсутствуют.

Цель работы - разработать критерии прогнозирования исхода острого периода МГСИ на основании оценки выраженности вторичного ВЖК в дебюте заболевания.

Материалы и методы. Проведено комплексное клинико-параклиническое исследование 70 пациентов (38 мужчин и 32 женщин, возраст - 66 (58; 74) лет) с подтвержденным по данным клинико-нейровизуализационного исследования Мгси и вторичного ВЖК, которые были госпитализированы в первые 24 часа от дебюта заболевания и получали консервативную терапию. Выраженность вторичного ВЖК оценивалась в баллах по Graeb Scale, Intraventicular hemorrhage (IVH) Scale и LeRoux Scale. Для определения критериев прогнозирования использовался ROC-анализ с расчетом параметров чувствительности (Se) и специфичности (Sp).

Результаты. Летальный исход был зарегистрирован в 18,6 \% случаев, относительно неблагоприятный исход в форме значения 4-5 баллов по модифицированной шкале Рэнкина (мШР) на 21 сутки заболевания - у 44,3 \% пациентов. Выявлено, что IVH Scale (AUC = 0,94, p < 0,05) превосходит по информативности Graeb Scale $(\mathrm{AUC}=0,89, \mathrm{p}<0,05)$ и LeRoux Scale (AUC = 0,88, p < 0,05) для прогнозирования летального исхода острого периода МГСИ. Установлено, что Graeb scale, IVH scale и LeRoux scale более информативны для определения витального, нежели функционального прогноза исхода острого периода МГСИ (AUC = 0,89 против AUC = 0,74 для Graeb scale, p < 0,05; AUC = 0,94 против $\mathrm{AUC}=0,79$ для IVH scale, $p<0,05 ; A U C=0,88$ против $A U C=0,72$ для LeRoux scale, $p<0,05)$.

Выводы. Предикторами летального исхода острого периода МГСИ выступают значения >5 баллов по Graeb Scale $(\mathrm{Se}=84,6 \%$, Sp = 77,2 \%), >16 баллов IVH Scale (Se = 84,6 \%, Sp = 96,5 \%) и >9 баллов по LeRoux Scale (Se = 84,6 \%, $\mathrm{Sp}=86,0 \%$ ). Критериями благоприятного функционального исхода острого пери ода МГСИ ( $\leq 3$ балла по мШР на 21 сутки заболевания) являются значения по Graeb Scale $\leq 3$ (Se = 69,2 \%, Sp = 72,7 \%), IVH Scale <8 (Se = 69,2 \%, Sp = 79,5 \%) и LeRoux Scale $\leq 3(\mathrm{Se}=69,2 \%, \mathrm{Sp}=72,7 \%)$.

\section{Introduction}

Cerebral hemorrhagic stroke (CHS) is the most destructive type of acute cerebrovascular accidents, which is at leading positions in the list of causes of death and disability in young and middle-aged people in most countries of the world $[1,2]$. The 30 -day mortality rate from $\mathrm{CHS}$ constitutes $35-52 \%$, and about $80 \%$ among survived patients, have severe consequences in the form of pronounced neurological deficit, which causes permanent disability and need for physical assistance in everyday life $[3,8]$.

$30-45 \%$ of cases of spontaneous intracerebral hemorrhage $(\mathrm{SICH})$ are complicated by intraventricular hemorrhage (IVH) [5,6]. In accordance with the numerous studies, the presence of secondary IVH is an independent predictor of early clinical deterioration and poor outcome in patients with $\mathrm{SICH}[4,9,10]$, which suggests the presence of secondary IVH in the spectrum of parameters associated with the acute period outcome of the disease [11].

\section{The aim}

Criteria for a short-term vital and functional prognosis for cerebral hemorrhagic supratentorial stroke (CHSS) acute period, that would take into account the secondary IVH severity in the onset of the disease, are currently lacking, and the aim of this study was to develop criteria for the prediction of cerebral hemorrhagic supratentorial stroke (CHSS) acute period outcome on the basis of the assessment of secondary intraventricular hemorrhage severity in the onset of the disease.

\section{Materials and methods}

A complex clinical and paraclinical study was conducted in 70 patients ( 38 men and 32 women, aged $66(58,74)$ years) who have CHSS and secondary IVH confirmed by a clinical and neuroimaging examination, who were hospitalized within the first 24 hours since the onset of the disease and received conservative therapy. The study excluded patients who have acute disorders of cerebral circulation in the anamnesis, oncological and/or decompensated somatic pathology. The cases of extracerebral cause of death in accordance with the autopsy results were also excluded.

The study included clinical and neurological examination along with the assessment on the basis of the National Institute of Health Stroke Scale (NIHSS) and Glasgow Coma Scale (GCS) in the onset of the disease. The assessment of the functional outcome of CHSS acute period and secondary IVH was held on the $21^{\text {st }}$ day of the disease according to the modified Rankin Scale (mRS), where mRS score $=4-5$ corresponded to an unfavorable functional outcome, $\mathrm{mRS}$ score $\leq 3$ - to a favorable one.

Acomputed tomography scanner "Siemens Somatom Spirit" was used for the visualization within the first 24 hours since the onset of the disease. Taking into consideration the lack of direct methods of the determination of IVH volume, its severity was assessed in terms of Graeb Scale, Intraventicular Hemorrhage (IVH) Scale and LeRoux Scale.

Statistical data analysis was carried out using Statistica 6.0 software (StatSoft Inc., USA, series number AXXR712D833214FAN5) and MedCalc (version 16.4). The normality was assessed using Shapiro-Wilk Test. Descrip-
Ключевые слова: внутримозговое кровоизлияние, компьютерная томография, прогноз.

Патология. - 2017. T. 14, № 3(41). C. $326-329$ 
Table 1. The results of the analysis of interrelation between the severity of secondary $\mathrm{IVH}$ and clinical and neurological data in patients on the basis of Spearman's rank correlation coefficient $(\mathrm{R})$

\begin{tabular}{llll}
\hline Scales & $\begin{array}{l}\text { NIHSS score } \\
\text { on the 1 } 1^{\text {st }} \text { day }\end{array}$ & $\begin{array}{l}\text { Glasgow Coma Scale } \\
\text { score on the 1 }\end{array}$ & $\begin{array}{l}\text { Modified Rankin } \\
\text { Scale score } \\
\text { on the 21 }\end{array}$ \\
\hline Graeb Scale score & $+0.44^{*}$ & $-0.40^{*}$ & $+0.54^{*}$ \\
IVH Scale score & $+0.54^{*}$ & $-0.50^{*}$ & $+0.64^{*}$ \\
LeRoux Scale score & $+0.43^{*}$ & $-0.39^{*}$ & $+0.51^{*}$ \\
\hline
\end{tabular}

*: $\mathrm{P}<0.05$.

Table 2. Analysis of differences of Graeb Scale score, IVH Scale score and LeRoux Scale score in groups of patients with lethal and non-lethal outcome of CHSS acute period, Me (Q1; Q3)

\begin{tabular}{llll}
\hline Scales & Lethal outcome $(\mathbf{n = 1 3 )}$ & $\begin{array}{l}\text { Non-lethal outcome } \\
(\mathbf{n = 5 7 )}\end{array}$ & $\mathbf{P}$ \\
\hline Graeb Scale score & $9(8 ; 10)$ & $4(2 ; 5)$ & $<0.0001$ \\
IVH Scale score & $20(17 ; 20)$ & $9(3 ; 13)$ & $<0.0001$ \\
LeRoux Scale score & $13(10 ; 14)$ & $4(2 ; 7)$ & $<0.0001$ \\
\hline
\end{tabular}

Table 3. Analysis of differences of Graeb Scale score, IVH Scale score and LeRoux Scale score in groups of patients with various functional outcomes of CHSS acute period, Me (Q1; Q3)

\begin{tabular}{llll}
\hline Scales & $\begin{array}{l}\text { Unfavorable functional out- } \\
\text { come }(\mathbf{n}=\mathbf{3 1})\end{array}$ & $\begin{array}{l}\text { Favorable functional } \\
\text { outcome }(\mathbf{n}=\mathbf{2 6})\end{array}$ & $\mathbf{P}$ \\
\hline Graeb Scale score & $5(2,75 ; 6)$ & $2(1,25 ; 4)$ & $<0.01$ \\
IVH Scale score & $11,5(6 ; 13)$ & $6(3 ; 9)$ & $<0.001$ \\
LeRoux Scale score & $5(2,75 ; 8)$ & $2(1,25 ; 4,75)$ & $<0.01$ \\
\hline
\end{tabular}

tive statistics were presented in the form of $\mathrm{Me}(\mathrm{Q} 1 ; \mathrm{Q} 3)$, where Me is the median, Q1 is the I quartile, Q3 is the III quartile. The interrelation of quantitative characteristics was assessed in accordance with the Spearman's rank correlation coefficient (R). Mann-Whitney Test was used to assess the intergroup differences. The null hypothesis was rejected with a significance level of statistical criteria $P<0.05$. To determine the prediction criteria, ROC analysis was used, calculating sensitivity (Se) and specificity (Sp) parameters.

\section{Results of research and discussion}

In the onset of the disease, the following indexes were registered in patients: NIHSS score $=12(8 ; 15)$, GCS score $=14(12 ; 15)$, Graeb Scale score $=4(2 ; 7)$, IVH Scale score $=10(6 ; 14)$ and LeRoux Scale score $=4.5(2 ; 10)$.

Acorrelation analysis was made to determine the level of interrelation between the severity of secondary IVH in patients with CHSS and clinical and neurological data in the acute period of the disease. The results of the analysis are presented in Table 1.

Direct relation between the severity of secondary IVH and the baseline level of neurological deficit, as well as the disability status on the $21^{\text {st }}$ day of the disease were moderate, which suggests the presence of Graeb Scale score, the IVH Scale score and the LeRoux Scale score in the spectrum of predictors of acute CHSS period outcome.

The following outcomes of the acute period of the disease were registered in patients: lethal outcome (18.6\%), unfavorable functional outcome in the form of $4-5$ points value in accordance with $\mathrm{mRS}(44.3 \%)$ and favorable functional outcome in the form of $\leq 3$ points value in accordance with $\mathrm{mRS}(37.1 \%)$.

The Graeb Scale score, IVH Scale score and LeRoux Scale score in the onset of the disease were significantly higher in patients with CHSS who had a lethal outcome in the acute period in comparison with patients with non-lethal outcome (Table 2).

On the basis of ROC-analysis it was determined that predictors of the acute period lethal outcome of the disease are: Graeb Scale score $>5(\mathrm{Se}=84.6 \%, \mathrm{Sp}=77.2 \%)$, IVH Scale score $>16(\mathrm{Se}=84.6 \%, \mathrm{Sp}=96.5 \%)$ and LeRoux Scale score $>9(\mathrm{Se}=84.6 \%, \mathrm{Sp}=86.0 \%)$.

It was determined that IVH Scale $(A U C=0.94)$ has a higher informative value than Graeb Scale (AUC $=0.89$, $P<0.05)$ and LeRoux Scale (AUC $=0.88, P<0.05)$ for CHSS acute period lethal outcome prediction.

It was detected that Graeb Scale score, IVH Scale score and LeRoux Scale score in the onset of the disease were significantly higher in patients with CHSS who had an unfavorable functional outcome in the acute period in comparison with patients with favorable functional outcome (Table 3).

It was determined that criteria for a favorable functional outcome of CHSS acute period are Graeb Scale score $\leq 3(\mathrm{Se}=69.2 \%, \mathrm{Sp}=72.7 \%)$, IVH Scale score $<8(\mathrm{Se}=69.2 \%, \mathrm{Sp}=79.5 \%)$ and LeRoux Scale score $\leq 3(\mathrm{Se}=69.2 \%, \mathrm{Sp}=72.7 \%)$, while the Graeb Scale score $=4-5$, IVH Scale score $=9-16$ and LeRoux Scale score $=4-9$ are associated with an unfavorable functional outcome.

It was found out that the predictive value of LeRoux scale (AUC $=0.72$ ) is inferior to that of IVH scale $(A \cup C=0.79, P<0.05)$ and Graeb scale $(A \cup C=0.74$, $P<0.05)$ as for the determination of the functional recovery level on the $21^{\text {st }}$ day since the onset of the disease.

On the basis of a comparative analysis of AUC indexes, it was determined that Graeb Scale, Intraventicular Hemorrhage Scale and LeRoux Scale are more informative for the determination of vital rather than functional prognosis of CHSS acute period outcome (AUC $=0.89$ versus AUC $=0.74$ for Graeb Scale, $P<0.05 ; A U C=0.94$ versus $\mathrm{AUC}=0.79$ for IVH Scale, $\mathrm{P}<0.05 ; \mathrm{AUC}=0.88$ versus $A \cup C=0.72$ for LeRoux Scale, $P<0.05$ ).

The obtained results are adjusted with the research conducted by B.Y. Hwang et al. 2012 in which the connection between higher Graeb Scale score, IVH Scale score, LeRoux Scale score and poor functional outcome was displayed, but any differences between informative values of IVH Scale, Graeb Scale and LeRoux Scales for a prediction of CHSS acute period functional outcome were not found there - areas under the receiver operating characteristic curve were similar among the IVH, Graeb, and LeRoux scores $(0.745,0.743$, and 0.744 , respectively) [7]. In our research it was claimed that IVH Scale is characterized by the highest informative value for prediction of CHSS with a secondary IVH acute period lethal outcome (AUC $=0.94$ versus $A U C=0.89$ for Graeb Scale and $A U C=0.88$ for LeRoux Scale) and for prediction functional recovery on the $21^{\text {st }}$ day of the disease $(A \cup C=0.79$ versus $A U C=0.74$ for Graeb Scale and AUC = 0.72 for LeRoux Scale). In our opinion, the results are due to the fact that IVH Scale 
allows a more differentiated assessment of the severity of IVH, as it takes into consideration the difference between the sizes of lateral cerebral ventricles and other ventricles.

Thus, the study made it possible to justify the use of assessment scales of the severity of secondary IVH in the onset of CHSS to predict the acute period outcome of the disease and to determine the values of the Graeb Scale, Intraventicular Hemorrhage Scale and LeRoux Scale by optimal sensitivity and specificity ratio. However, further research is needed to obtain more informative criteria for the prediction of the functional outcome of CHSS acute period along with a secondary IVH.

\section{Conclusions}

1. Predictors of the lethal outcome of CHSS acute period are Graeb Scale score $>5(\mathrm{Se}=84.6 \%, \mathrm{Sp}=77.2 \%)$, IVH Scale score $>16(\mathrm{Se}=84.6 \%, \mathrm{Sp}=96.5 \%)$ and LeRoux Scale score $>9(\mathrm{Se}=84.6 \%, \mathrm{Sp}=86.0 \%)$.

2. Graeb Scale score $\leq 3(\mathrm{Se}=69.2 \%, \mathrm{Sp}=72.7 \%)$, IVH Scale score $<8(\mathrm{Se}=69.2 \%, \mathrm{Sp}=79.5 \%)$ and LeRoux Scale score $\leq 3 \mathrm{Se}=69.2 \%, \mathrm{Sp}=72.7 \%$ ) are the criteria for the favourable functional outcome of CHSS acute period (mRS score $\leq 3$ on the $21^{\text {st }}$ day).

3 . The predictive value of Intraventricular Hemorrhage Scale (AUC $=0.94$ ) is superior to Graeb Scale $(A \cup C=0.89, P<0.05)$ and LeRoux Scale $(A \cup C=0.88$, $\mathrm{P}<0.05)$ as for the definition of the vital prognosis of CHSS acute period outcome.

4. LeRoux Scale (AUC $=0.72)$ is less informative than IVH Scale (AUC $=0.79, P<0.05)$ and Graeb Scale $(A \cup C=0.74, P<0.05)$ as for the prediction of the functional outcome of CHSS acute period.

5. Graeb Scale, Intraventicular Hemorrhage Scale and LeRoux Scale are more informative as for the determination of vital, rather than functional outcome of CHSS acute period.

The perspective for the further scientific research is the elaboration of the differential approach for the optimal treatment choice in patients with CHSS and secondary IVH on the ground of individual acute period outcome prognosis.

\section{References}

[1] Ministerstvo okhorony zdoroviia Ukrayiny (2014). Adaptovana klinichna nastanova «Hemorahichnyi insult. Spontannyi vnutrishnomozkovyi krovovylyv». [Adapted clinical guidance «Hemorrhagic stroke. Subarachnoid hemorrhage»]. Retrived from http://mtd.dec.gov.ua/images/ dodatki/2014_275_GI/2014_275 AKN_vnytrkrov_GI.pdf.

[2] Mishchenko, T. S. (2017). E'pidemiologiya cerebrovaskulyarnykh zabolevanij i organizaciya pomoschi bol'nym s mozgovym insul'tom v Ukraine [Epidemiology of cerebrovascular diseases and organization of medical care for patients with stroke in Ukraine]. Ukrainskyi visnyk psykhonevrolohii, 1(90), 22-24. [in Russian].

[3] An, S. J., Kim, T. J., \& Yoon, B. W. (2017). Epidemiology, Risk Factors, and Clinical Features of Intracerebral Hemorrhage: An Update. J Stroke, 19(1), 3-10. doi: 10.5853/jos.2016.00864.

[4] Chen, C. W., Wu, E. H., Huang, J., Chang, W. T., Ao, K. H., Cheng, T. J., \& Yang, W. (2016). Dynamic evolution of D-dimer level in cerebrospinal fluid predicts poor outcome in patients with spontaneous intracerebral hemorrhage combined with intraventricular hemorrhage. J Clin Neurosci, 29, 149-154. doi: 10.1016/j.jocn.2015.10.036.

[5] Chen, S., Zhao, B., Wang, W., Shi, L., Reis, C., \& Zhang, J. (2017). Predictors of hematoma expansion predictors after intracerebral hemorrhage. Oncotarget, 8(51), 89348-89363. doi: 10.18632/oncotarget.19366.
[6] Garton, T., Hua, Y., Xiang, J., Xi, G., \& Keep, R. F. (2017). Challenges for intraventricular hemorrhage research and emerging therapeutic targets. Expert Opin Ther Targets, 21(12), 1111-1122. doi: 10.1080/14 728222.2017.1397628.

[7] Hwang, B. Y., Bruce, S. S., Appelboom, G., Piazza, M. A., Carpenter, A. M., Gigante, P. R., et al. (2012). Evaluation of intraventricular hemorrhage assessment methods for predicting outcome following intracerebral hemorrhage. J Neurosurg, 116(1), 185-192. doi: 10.3171/2011.9.JNS10850.

[8] Krishnamurthi, R. V., Feigin, V. L., Forouzanfar, M. H., Mensah, G. A. Connor, M., Bennett, D. A., et al. (2013). Global Burden of Diseases, Injuries, Risk Factors Study 2010 (GBD 2010); GBD Stroke Experts Group. Global and regional burden of first-ever ischaemic and haemorrhagic stroke during 1990-2010: findings from the Global Burden of Disease Study 2010. Lancet Glob Health, 1(5), e259-281. doi: 10.1016/ S2214-109X(13)70089-5.

[9] Specogna, A. V., Turin, T. C., Patten, S. B., \& Hill, M. D. (2014). Factors associated with early deterioration after spontaneous intracerebral hemorrhage: a systematic review and meta-analysis. PLoS One, 9(5), e96743. doi: 10.1371/journal.pone.0096743.

[10] Ye, Z., Ai, X., Hu, X., Fang, F., \& You, C. (2017). Clinical features and prognostic factors in patients with intraventricular hemorrhage caused by ruptured arteriovenous malformations. Medicine (Baltimore), 96(45), e8544. doi: 10.1097/MD.0000000000008544.

[11] Yuan, R., Lei, C., Wu, S., Wei, C., Xiong, Y., Xu, M., et al. (2017). Prognostic Significance of Intraventricular Hemorrhage in Vascular Structural Abnormality-Related Intracerebral Hemorrhage. J Stroke Cerebrovasc Dis, 26(3), 636-643. doi: 10.1016/j.jstrokecerebrovasdis.2016.11.012.

\section{Information about author:}

Kuznietsov A. A., MD, PhD, Associate Professor of Department

of Nervous Diseases, Zaporizhzhia State Medical University, Ukraine.

\section{Відомості про автора:}

Кузнєцов А. А., канА. меА. наук, Аоцент каф. нервових хвороб, Запорізький державний медичний університет, Україна.

\section{Сведения об авторе:}

Кузнецов А. А., канА. меА. наук, Аоцент каф. нервных болезней, Запорожский государственный меАицинский университет, Украина.

Conflicts of Interest: author has no conflict of interest to declare. Конфмікт інтересів: віАсутній.

Надійшло Ао редакції / Received: 09.10.2017

Після Аоопрацювання / Revised: 16.10.2017

Прийнято Ао Аруку / Accepted: 27.10.2017 